\title{
Lecanora sorediomarginata, a new epiphytic lichen species discovered along the Portuguese coast
}

\author{
Sandrina Azevedo RODRIGUES, Arsenio TERRÓN-ALFONSO, \\ John A. ELIX, Sergio PÉREZ-ORTEGA, Tor TØNSBERG, \\ Ana Belén FERNÁNDEZ-SALEGUI and \\ Amadeu M. V. M. SOARES
}

\begin{abstract}
Lecanora sorediomarginata Rodrigues, Terrón \& Elix sp. nov., described as new to science from Portugal, is characterized morphologically by a crustose whitish-grey to greenish thallus developing soralia from small, marginal warts and chemically by the presence of 3,5-dichloro-2'-Omethylnorstenosporic acid [major], 3,5-dichloro-2'-O-methylanziaic acid [minor], 3,5-dichloro- $2^{\prime}$ $O$-methylnordivaricatic acid [minor], 5-chloro-2'-O-methylanziaic acid [trace], atranorin [minor], chloroatranorin [minor], and usnic acid [trace]. It is chemically similar to L. lividocinerea, to which it shows phylogenetic affinities based on ITS rDNA sequence analysis, and to L. sulphurella. Lecanora sorediomarginata is epiphytic on Pinus pinaster and P. pinea, in pine forests on sand dunes along the Portuguese coast.
\end{abstract}

Keywords: ITS rDNA, Lecanoraceae, pine forests, sand dunes, taxonomy

\section{Introduction}

Lecanora Ach. (Lecanoraceae) is a large genus comprising c. 800 species and is defined by hyaline and simple spores, Lecanora-type asci, green algal photobionts, an usually thalline margin of the apothecium and generally a crustose thallus (LaGreca \& Lumbsh 2001; Pérez-Ortega et al. in press). Lecanora s. str. comprises $c .300$ species and is characterized

S. A. Rodrigues and A. M. V. M. Soares: CESAM \& Departamento de Biologia, Universidade de Aveiro, Campus Universitário de Santiago, 3810-193 Aveiro, Portugal. Email rodrigues.s@ua.pt

A. Terrón-Alfonso and A. B. Fernández-Salegui: Departamento de Biodiversidad y Gestión Ambiental, Área Botánica, Facultad de Biología y Ciencias Ambientales, Universidad de León, Campus Vegazana S/N, 24071, Léon, Spain.

J. A. Elix: Research School of Chemistry, Building 33, Australian National University, Canberra ACT 0200, Australia.

S. Pérez-Ortega: Instituto de Recursos Naturales, Centro de Ciencias Medioambientales (CSIC), c/ Serrano 115 dpdo, E-28006 Madrid, Spain.

T. Tønsberg: Museum of Natural History, University of Bergen, Allégaten 41, P. O. Box 7800, N-5020 Bergen, Norway. by the presence of oxalate crystals in the amphithecium and the production of atranorin and/or usnic acid in the cortex (LaGreca \& Lumbsch 2001). This genus has been divided into several groups, which were until recently circumscribed using morphological, anatomical or chemical characters (Arup \& Grube 1998). In recent years, molecular studies began clarifying the phylogenetic relationships in and between some of these groups. These indicate that Lecanora s. str. is a heterogenous assemblage of species (Grube et al. 2004), but the relationships between groups are still largely unresolved (Pérez-Ortega et al. in press).

The core of Lecanora is the L. subfusca group, which contains the type species $L$. allophana Nyl., and is identified by the presence of a crustose thallus containing atranorin, either as a major or trace constituent; as well as crystals in the amphithecium and filiform conidia (Lumbsch et al. 2003). So far, no phylogenetic studies have been performed in order to assess the phylogenetic relationships of species currently included in this group, although some were used in 
studies relative to other groups, namely on the subgenus Placodium and the L. rupicola and $L$. varia groups. Both the subgenus Placodium and the $L$. varia group were found to be heterogenous, and some species considered to belong here were found to group with other Lecanora groups (Arup \& Grube 1998; Pérez-Ortega et al. in press). The L. rupicola group, previously circumscribed to saxicolous species containing sordidone, was found to be monophyletic and including all species containing sordidone, regardless of their substratum, such as the corticolous species of the L. carpinea group (Grube et al. 2004). Further, it has been shown that the genus Rhizoplaca Zopf is polyphyletic and is nested within several groups of Lecanora (Arup \& Grube 2000). More studies are therefore needed to clarify the phylogenetic relationships between members of Lecanora, which may require more intensive taxon sampling (PérezOrtega et al. in press).

Lecanora sorediomarginata sp. nov. was discovered at Dunas de Quiaios (Figueira da Foz) on the central west coast of Portugal. It is epiphytic on Pinus pinaster Aiton and $P$. pinea L. Dunas de Quiaios is a pine forest on a sand dune area, which was scarcely vegetated until 1924 (Almeida 1997). In that year the Portuguese Forest Services started stabilizing the dunes by sowing $P$. pinaster, the species selected to promote dune stabilization, together with Acacia longifolia (Andrews) Willd, $A$. retinoides Schltdl., Corema album (L.) D. Don, Myrica faya Aiton and Ulex europaeus L., in the interior dunes. Since the original seeding, Cistus salvifolius L., Cytisus grandiflorus (Brot.) DC., Halimium halimifolium (L.) Willk., $H$. calycinum (L.) K. Koch and Lavandula stoechas L. subsp. sampaiana Rozeira have spontaneously naturalized and proliferated in the area (Almeida 1997). Other species occurring in secondary dunes include Acacia melanoxylon R. Br., Arbutus unedo L., Eucalyptus globulus Labill. and P. pinea, the last thought by some authors to be the original forest species of these sand dunes (Danielsen 2008). In the depressions and flat surfaces of these dunes hygrophilic species such as
Schoenus nigricans L. and Scirpus holoschoenus L., among others, can be detected (Almeida 1997).

This pine forest on sand dunes is rich in epiphytic and terrestrial lichens. The most abundant epiphytic lichens are Chrysothrix candelaris (L.) J. R. Laundon and Pyrrhospora quernea (Dicks.) Körb., followed by Hypogymnia physodes (L.) Nyl., Flavoparmelia caperata (L.) Hale, Parmotrema reticulatum (Taylor) M. Choisy, Usnea rubicunda Stirt. and $U$. subscabrosa Nyl. ex Motyka. Other interesting species have also been found here, including Hypotrachyna lividescens (Kurok.) Hale and $H$. pseudosinuosa (Asahina) Hale, species not previously known from the Iberian Peninsula (Rodrigues et al. 2007). Chrysothrix flavovirens Tønsberg, Lepraria elobata Tønsberg and Ochrolechia arborea (Kreyer) Almb. have also been found at Dunas de Quiaios and are novelties for the Portuguese lichen flora (S. A. Rodrigues et al., unpublished data).

Pine forests on sand dunes are common along the Portuguese coast. The most famous is probably the pine forest of Leiria known as "Pinhal de Leiria", where seeding was greatly encouraged by king D. Dinis (13-14th century) (Arroteia 2009). Given the large number of pine forests on sand dunes along the coast, surveys were undertaken in other similar areas, ranging from north to south-eastern Portugal (Fig. 1) in search of $L$. sorediomarginata. In most of the forests the main phorophyte is $P$. pinaster, but in Mata de Valverde (Alcácer do Sal) (Fig. 1, 21) $P$. pinea is the main phorophyte. Some neighbouring mountains beyond the sand dunes were also visited, including Serra da Boa Viagem (Figueira da Foz) (Fig. 1, 9) and Serra de Sintra (Sintra) (Fig. 1, 17). The type locality, Dunas de Quiaios (Figueira da Foz) (Fig. 1, 8), as well as several of the localities visited are national forests or forest perimeters owned and/or partially managed by Portuguese Forest Services (Fig. 1, 3, 5-14, 17, 21-22). Some areas are within Natural Parks or Nature Reserves, as is the case of the Natural Parks of Litoral Norte (Fig. 1, 1), Sintra-Cascais (Fig. 1, 16, 17), Arrábida (Fig. 1, 18) and Sudoeste Alentejano e Costa 


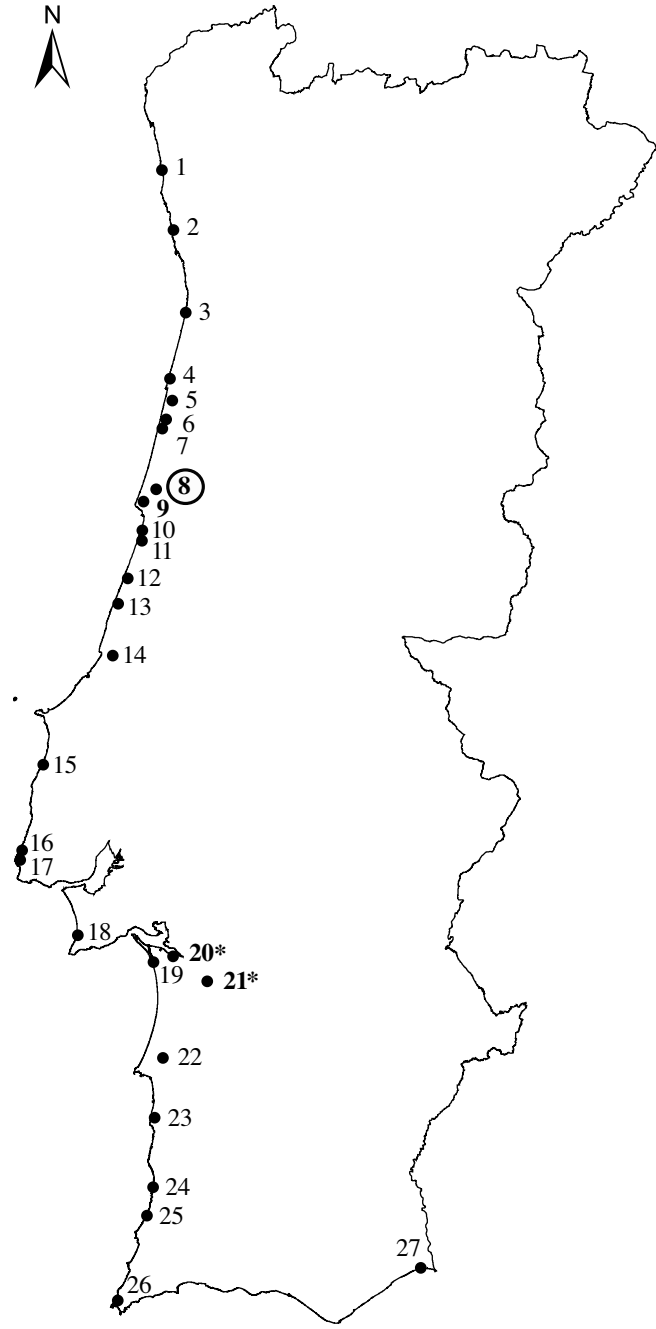

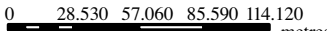

FIG. 1. Locations where Lecanora sorediomarginata was found along the Portuguese coast. 1- Fão (Esposende), 2- Parque de Campismo de Angeiras (Matosinhos), 3- Dunas de Ovar (Ovar), 4- Dunas de S. Jacinto (Aveiro), 5- Dunas da Gafanha (Ílhavo), 6- Dunas de Vagos (Vagos), 7- Dunas de Mira (Mira), 8- Dunas de Quiaios (Figueira da Foz), 9- Mata do Prazo de Santa Marinha/Serra da Boa Viagem (Figueira da Foz), 10- Dunas da Leirosa (Figueira da Foz), 11- Mata do Urso (Figueira da Foz), 12- Mata do Pedrógão (Leiria), 13- Pinhal de Leiria (Marinha Grande), 14- Mata do Valado (Nazaré), 15- Praia do Seixo (Torres Vedras), 16- Praia das Maçãs (Sintra), 17- Serra de Sintra (Sintra), 18- Praia do Moinho de Baixo (Sesimbra), 19- Praia da Comporta (Alcácer do Sal), 20- Murta (Alcácer do Sal), 21-Mata de Valverde (Alcácer do Sal),
Vicentina (Fig. 1, 23-26); and of the Nature Reserves of S. Jacinto (Fig. 1, 4) and of Estuário do Sado (Fig. 1, 19-20). Most of the areas surveyed belong to the Natura 2000 Network (Fig. 1, 1, 4, 6-8, 15, 17-20, 2327), Dunas de Quiaios being part of the Site "Dunas de Mira, Gândara e Gafanhas" (PTCON0055) (ICN 2006).

\section{Materials and Methods}

The morphology of the thallus was examined under stereomicroscopes and images were taken with a stereomicroscope (Nikon SMZ1500), using the program NISElements (Nikon). The measurement of morphological structures, such as wart size, diameter of apothecia and thickness of the apothecial margin were made using a Leica MS5 stereomicroscope. The thickness of the thallus, as well as the size of consoredia and soredia, were made in samples mounted in lactophenol cotton blue and viewed under a Leitz HM-LUX 3 microscope.

Anatomical observations of the apothecia were performed on hand-cut sections and also on microtome sections mounted in $\mathrm{K} / \mathrm{I}$ and lactophenol cotton blue. For obtaining microtome sections, apothecia were placed in gelatine (Tissue-Tek, Sakura), frozen inside a microtome (Microm HM $505 \mathrm{E}$ ) at $-20^{\circ} \mathrm{C}$, and $14 \mu \mathrm{m}$ thick sections cut. Sections for spot tests with $\mathrm{K}$ and $\mathrm{C}$ were mounted in distilled water. The same procedure was used for viewing the reactions of the epihymenial crystals following the addition of $\mathrm{K}$ and $\mathrm{HNO}_{3}$. Images of the apothecial sections were taken with an epifluorescence microscope (Optihot 2, Nikon), using the imaging program NIS-Elements (Nikon). Images were taken under normal and polarized light and under a UV excitation filter (EX 330-380 nm, DM $400 \mathrm{~nm}$ and BA $420 \mathrm{~nm})$.

SEM imaging of both hand-cut and microtome sections of apothecia and of consoredia and soredia was performed with a Scanning Electron Microscope (JSM6480LV, JEOL). Apothecial sections were mounted on SEM holders and covered with gold in a Sputter Coater (SCD 004, Balzers).

Specimens were analyzed chemically by standardized thin-layer chromatographic methods (TLC) (White \&

22- Área Florestal de Sines (Santiago do Cacém), 23- Praia do Malhão (Odemira), 24- Praia do Carvalhal (Odemira), 25- Praia de Vale dos Homens (Aljezur), 26- Pinhal de Vale Santo (Vila do Bispo), 27-Dunas de Vila Real de Santo António (Vila Real de Santo António). Numbers in bold refer to locations where $L$. sorediomarginata was found both on Pinus pinaster and $P$. pinea, while numbers in bold and with an asterisk refer to locations where this species was found only on $P$. pinea. The encircled number refers to the type locality. 
James 1985; Elix \& Ernst-Russell 1993; Orange et al. 2001) and by high performance liquid chromatography (HPLC) (Elix et al. 2003).

Confirmation of the identity of $L$. sorediomarginata from distinct localities was performed by morphological and chemical analysis (TLC) of one to three specimens from each location.

The locations visited were georeferenced using GoogleEarth and maps were plotted using ArcGis version 9.2 .

\section{Phylogenetic analysis}

For DNA extraction, soredia and apothecia were used from $L$. sorediomarginata and L. lividocinerea Bagl. respectively; they were separated from the thallus with the help of forceps. Special care was taken to avoid areas with possible contaminating fungi. Samples were extracted using the DNEasy Plant Mini Kit (Qiagen ${ }^{\circledR}$ ), following the manufacturer's protocol, with minor modifications (Crespo et al. 2001). PCR reactions were prepared for a $25 \mu \mathrm{l}$ final volume, containing $1.25 \mu \mathrm{l}$ of each primer $(10 \mu \mathrm{M}), 17 \cdot 5 \mu \mathrm{l}$ of distilled water and $5 \mu \mathrm{l}$ of the DNA template; PuReTaq Ready-To-Go PCR beads (GE Health Care, Amersham Biosciences, 2004) were added to the mix according to the manufacturer's instructions. PCR amplifications were carried out in a PTC-100 Peltier ${ }^{\circledR}$ Thermal Cycler, using the following conditions: initial denaturation for $4 \mathrm{~min}$ at $94^{\circ} \mathrm{C}$, followed by 3 cycles of $1 \mathrm{~min}$ at $94^{\circ} \mathrm{C}, 1.30 \mathrm{~min}$ at $54^{\circ} \mathrm{C}$ and $1.45 \mathrm{~min}$ at $72^{\circ} \mathrm{C}$; then 30 cycles of $1 \mathrm{~min}$ at $94^{\circ} \mathrm{C}, 1 \mathrm{~min}$ at $48^{\circ} \mathrm{C}$ and $1.45 \mathrm{~min}$ at $72^{\circ} \mathrm{C}$, and final elongation for $7 \mathrm{~min}$ at $72^{\circ} \mathrm{C}$. The following primers were used for PCR amplifications: ITS1F (Gardes \& Bruns 1993), ITS4 (White et al. 1990), ITS1LM (Myllys et al. 1999) and ITS2KL (Lohtander et al. 1998). PCR products were purified using QIAquick PCR Purification Kit

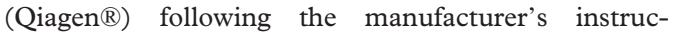
tions. Both complementary strands were sequenced by Secugen (CIB, Madrid), using the BigDye ${ }^{\circledR}$ Terminator v3.1. Sequence fragments obtained were checked, assembled and edited in SeqMan v.7 (Lasergene ${ }^{\circledR}$ ).

\section{Sequence alignment}

Amplicons obtained from our samples were aligned with members of the genus Lecanora found in GenBank, trying to encompass the highest diversity within the genus. For that, members of $L$. dispersa, polytropa, rupicola, subfusca, symmicta and varia groups, as well as of the Protoparmeliopsis group were used in the analysis, corresponding to a total of 47 ingroup and 1 outgroup taxa (Fapewia tornoensis (Nyl.) Tønsberg) (Table 1). Alignments were constructed using Muscle v3.6 (Edgar 2004) and subsequently checked and improved by hand. Ambiguously aligned regions were removed from the alignment using Gblocks 0.91b (Castresana 2000). Nucleotide substitution models were statistically selected with the help of jModelTest (Posada 2008, program available at http://darwin.uvigo.es. Model selection was made according to the Akaike information criterion (AIC, Akaike 1974); the General Time
Reversible substitution model (Tavaré 1986), with a proportion of invariant sites and site specific substitution rates following a gamma distribution with six rate categories $(\mathrm{GTR}+\mathrm{I}+\mathrm{G})$, had the lowest $-\ln L$ value according to the AIC. Bayesian analyses were carried out using MrBayes, version 3.1.2 (Huelsenbeck \& Ronquist 2001). The (MC) $)^{3}$ analysis was run for $5000 \mathrm{~K}$ generations starting from a random tree, employing 8 simultaneous chains and using the default temperature of $0 \cdot 2$. Every 200th tree was sampled and the first 5000 trees were discarded as burn-in. Posterior probabilities of each branch were calculated by counting the frequency of trees that were visited during the course of the $\mathrm{B} / \mathrm{MCMC}$ analysis. The $50 \%$ majority-rule consensus tree was obtained from the remaining trees. Trees were visualized using the program Treeview (Page 1996).

\section{Taxonomic Description}

\section{Lecanora sorediomarginata Rodrigues, Terrón \& Elix sp. nov.}

\section{MycoBank MB 518287}

Thallus crustaceus, cretaceo-griseus usque ad viridis, verruculosus et cum sorediis. Prothallus cretaceus, ad thalli marginem et inter verrucas visibilis. Soredia verrucularum exorientes, initium sejuncta, sed posterius confluentia ad matura thalli partes. Soredia composita per tenuia soredia et consoredia. Photobiont Trebouxia. Apothecia lecanorina, rara, sejuncta vel aggregata, sessilia, 0.37-1.25 mm diam. Discus epruinosus, pallide vel obscure brunneus. Excipulum thallinum flexuosum, cum sorediis. Epihymenium brunneum, propter crystallorum brunneorum praesentiam, inspersum. Sporae ellipsoidales, incoloratae, simplices vel monoseptatae, $4.0-8.5 \times 6.5-11.5 \mu \mathrm{m}$. Hypothecium hyalinum, algarum stratum absens. Thallus continens acidum 3,5dichlorinum-2'-O-methylnorstenosporicum [major] et vestigiae plurium acidorum aliorum.

Typus: Portugal, Beira Litoral, Figueira da Foz, Dunas de Quiaios, MGRS: 29TNE1654, $49 \mathrm{~m}$ alt., epiphytic on Pinus pinaster in a pine forest on sand dunes, 15 December 2006, S. A. Rodrigues AVE-L 197 (AVE-L-holotypus; LEB- Lichenes 7581-isotypus).

(Fig. 2)

Thallus crustose, corticolous, whitish-grey to greenish, appearing as separate patches in distinct scales of Pinus bark, or forming a continuous crust up to $8 \mathrm{~cm}$ wide. Margin endosubstratal to very thinly episubstratal, (0) $7 \cdot 5-(28 \cdot 0)-52 \cdot 0 \mu \mathrm{m}$ thick $(n=9)$ or forming small warts, $0 \cdot 07-(0 \cdot 14)-0.25 \mathrm{~mm}$ diam. $(n=74)$ (Fig. 2A). In certain older areas of the thallus, it may become more 
TABLE 1. ITS rDNA sequences used in the phylogenetic analysis of Lecanora sorediomarginata and their GenBank accession numbers (newly produced sequences in bold)

\begin{tabular}{|c|c|}
\hline Species & $\begin{array}{c}\text { GenBank Accession } \\
\text { Number (ITS nr DNA) }\end{array}$ \\
\hline Fapewia tornoensis & EF495163 \\
\hline Lecanora albella 1 & AY541240 \\
\hline L. albella 2 & AY541241 \\
\hline L. albescens & AF070033 \\
\hline L. allophana 1 & AF070031 \\
\hline L. allophana 2 & AF159939 \\
\hline L. bicincta & DQ451664 \\
\hline L. bipruinosa & $\mathrm{AF} 159932$ \\
\hline L. caesiorubella & AY541245 \\
\hline L. campestris & AF159930 \\
\hline L. carpinea & AY541249 \\
\hline L. cateilea & AY541250 \\
\hline L. cenisia & EU558541 \\
\hline L. chlorophaeodes 1 & AF070029 \\
\hline L. chlorophaeodes 2 & AY398704 \\
\hline L. concolor & AF070037 \\
\hline L. conizaeoides & AF 189717 \\
\hline L. contractula & AF070032 \\
\hline L. dispersa & EU266081 \\
\hline L. dispersoareolata & AF070016 \\
\hline L. epibryon & AY541251 \\
\hline L. flotowiana & $\mathrm{AF} 070034$ \\
\hline L. garovaglii & AF 189718 \\
\hline L. horiza & AY541252 \\
\hline L. hybocarpa & DQ782849 \\
\hline L. intricata & AY398703 \\
\hline L. intumescens 1 & AY541253 \\
\hline L. intumescens 2 & AY541254 \\
\hline L. lividocinerea & GU480123 \\
\hline Lecanora lojkaeana & AY541256 \\
\hline L. macrocyclos & AF159933 \\
\hline L. muralis & FJ497040 \\
\hline L. nashii 1 & AF159931 \\
\hline L. nashii 2 & AY398702 \\
\hline L. orosthea & AY398701 \\
\hline L. paramerae & EF105413 \\
\hline L. perpruinosa & AF070025 \\
\hline L. polytropa & DQ534470 \\
\hline L. pulicaris & AF101274 \\
\hline L. reuteri & AF070026 \\
\hline L. rugosella & AY398712 \\
\hline L. rupicola 1 & DQ451669 \\
\hline L. rupicola 2 & DQ451667 \\
\hline L. rupicola 3 & DQ451670 \\
\hline L. saligna & AF189716 \\
\hline L. sorediomarginata 1 & GU480121 \\
\hline L. sorediomarginata 2 & GU480122 \\
\hline L. straminea & AY398700 \\
\hline L. subcarpinea & DQ451657 \\
\hline L. subrugosa & AY398711 \\
\hline L. sulphurea & AF070030 \\
\hline L. swartzii & DQ451656 \\
\hline L. varia 1 & $\mathrm{AF} 070021$ \\
\hline L. varia 2 & AF070028 \\
\hline Rhizoplaca aspidophora & DQ534484 \\
\hline$R$. chrysoleuca & EU586515 \\
\hline R. huashanensis & AY530885 \\
\hline
\end{tabular}

obviously episubstratal and up to $38 \cdot 0$ $(213 \cdot 5)-1184.5 \mu \mathrm{m}$ thick $(n=9)$. Prothallus whitish, visible at thallus margin and around warts. A black border line sometimes present between neighbouring thalli, or when in contact with $P$. quernea or L. lividocinerea; otherwise not visible. Thallus sorediate; soredia arising from rupture of episubstratal warts. Soralia initially isolated and sparse but becoming dense or coalescing in older areas of the thallus (Fig. 2B), composed of both fine soredia and consoredia. Consoredia greenish in the upper part and whitish grey in the lower part, coarse, somewhat elongate, $22 \cdot 5-(45 \cdot 0)-139 \cdot 0 \times 35 \cdot 0-(54 \cdot 5)-147 \cdot 0 \mu \mathrm{m}$ $(n=47)$, wall indistinct (Fig. 2C). Fine soredia usually rounded, \pm slightly elongated, 16.0-(22.5)-37.0 × 17.0-(25.5)-37.0 $\mu \mathrm{m}$ $(n=57)$. Medulla not observed. Photobiont Trebouxia, 4.0-(8.5)-11.5 $\mu \mathrm{m}$ diam.

Apothecia rare, scattered or grouped, lecanorine, sessile, $0 \cdot 37-(0 \cdot 76)-1 \cdot 25 \mathrm{~mm}$ diam. $(n=19)$ (Fig. 2D). Disc epruinose, pale to dark brown; amphithecium flexuose, sorediate, concolorous with the thallus, usually persistent, but sometimes consoredia eroded from part of the margin, (0) $0 \cdot 05-(0 \cdot 12)$ $0.22 \mathrm{~mm}$ wide. Epihymenium brownish due to the presence of fine brown crystals, crystals soluble in $\mathrm{KOH}$, insoluble in $\mathrm{HNO}_{3}$, pulicaris-type (Brodo 1984), talso present in the hymenium and subhymenium (POL+) (Fig. 2E), inspersed with small oil droplets. Hymenium hyaline, $60 \cdot 0-(68 \cdot 0)-82 \cdot 0 \mu \mathrm{m}$ high $(n=5)$, I+ blue; inspersed with oil droplets. Paraphyses septate, branched at the base of the hymenium or in the subhymenium, not capitate, slightly bent near the tip, leptodermatous type, c. $1 \cdot 0 \mu \mathrm{m}$ diam. Subhymenium 41.0-54.0-65.0 $\mu \mathrm{m}$ thick $(n=5)$. Hypothecium hyaline, $140 \cdot 0-(150 \cdot 0)-$ $160.0 \mu \mathrm{m}$ thick $(n=4)$ in the centre; algal layer not present. Parathecium hyaline, 23.0 $(29 \cdot 0)-50 \cdot 0 \mu \mathrm{m}$ thick at the extremity of the apothecia. Amphithecium entire in very early stages, but then completely composed of consoredia, lacking medulla and cortex, with small crystals (POL+), 451.0-(474.0)-526.5 $\mu \mathrm{m}$ thick $(n=5)$ near the parathecium. Asci clavate $\quad 32.0-(42.5)-50.0 \times 12.5-(15.5)-$ $19 \cdot 0 \mu \mathrm{m}(n=7)$. Spores ellipsoid, hyaline, 

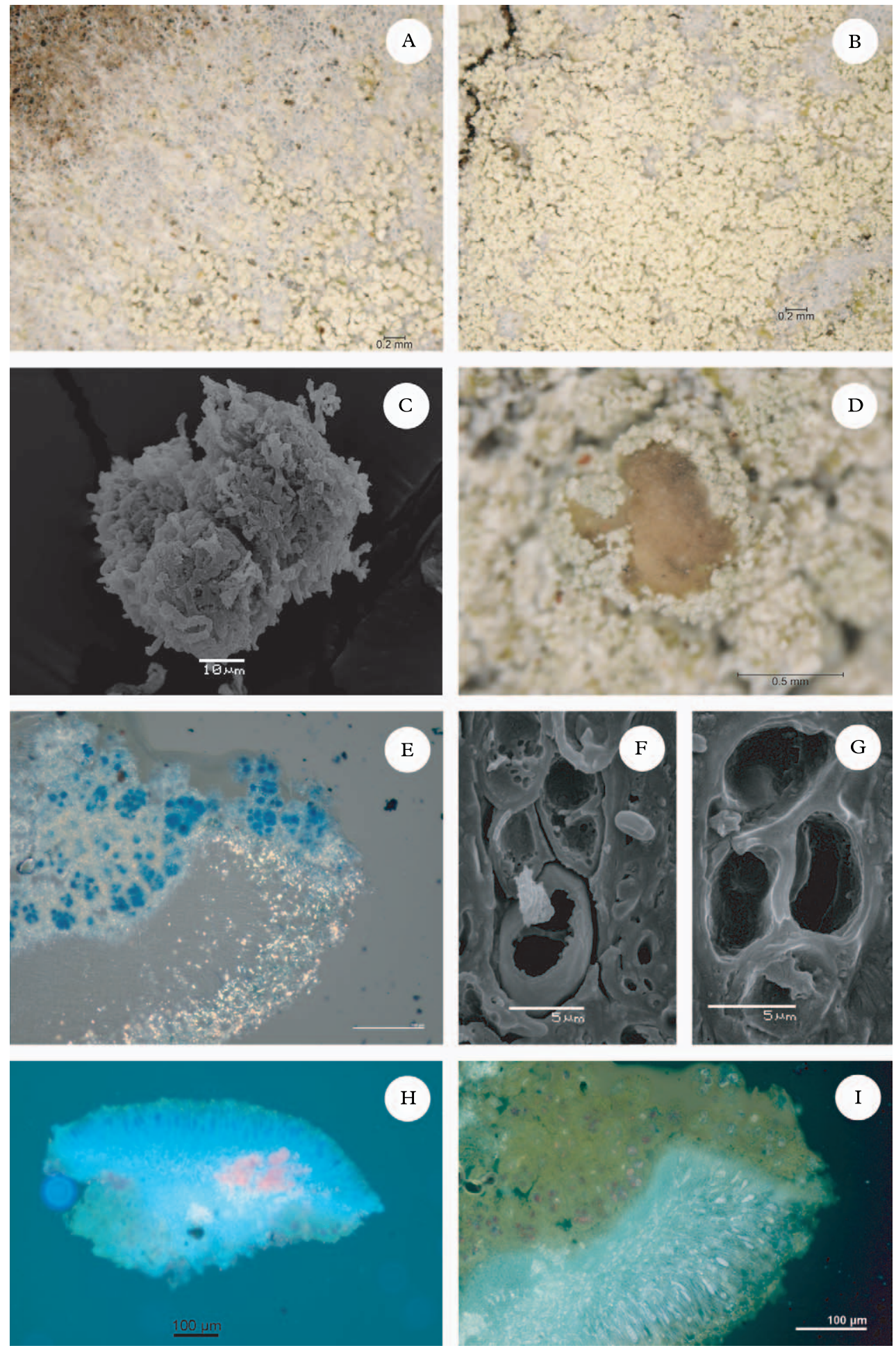
simple or monoseptate, $4 \cdot 0-(6 \cdot 5)-8.5 \times$ 6.5-(10.0)-11.5 $\mu \mathrm{m}(n=96)$ (Fig. $2 \mathrm{~F} \& \mathrm{G})$.

Chemistry. Soralia $\mathrm{P}-, \mathrm{K}-$ or +yellow, $\mathrm{KC}+$ red, $\mathrm{C}+$ red. Contains: 3,5-dichloro-2'-Omethylnorstenosporic acid [major], 3,5dichloro-2'-O-methylanziaic acid [minor], 3,5-dichloro-2'-O-methylnordivaricatic acid [minor], 5-chloro-2'-O-methylanziaic acid [trace], atranorin [minor], chloroatranorin [minor], and usnic acid [trace].

Large droplets of one or several substances that fluoresce red when a UV (330-380 nm) filter is applied were observed in the hypothecium, subhymenium and parathecium (Fig. 2H). These were larger than the oil droplets present in the hymenium and epihymenium. The presence of one or more additional substances that fluoresce yellow under the same filter were also detected in the epihymenium and amphithecium, as well as in the consoredia beneath the apothecium (Fig. 2I). These UV+ substances do not entirely coincide with the POL + crystals, at least not in the epihymenium.

Etymology. The specific epithet "sorediomarginata" refers to the nature of the margin of the apothecia of $L$. sorediomarginata, which is completely sorediate at maturity.

Substratum. Bark of trunks and branches of Pinus pinaster and P. pinea.

Distribution. Occurs in coastal pine forests, as well as in nearby mountains, along the west coast of Portugal, south of Esposende (Fig. 1, 1), as well as in the south-eastern coast. It was found at varying distances from the sea, from approximately $260 \mathrm{~m}$ at Praia de Vale dos Homens (Rogil, Parque Natural do Sudoeste Alentejano e Costa Vicentina) (Fig. 1, 25) to approximately $22 \mathrm{~km}$ at Mata de Valverde (Alcácer do Sal) (Fig. 1, 21). It was found at approximately $34 \mathrm{~m}$ from the Sado Estuary (Fig. 1, 19). Although surveys were conducted north of Esposende at Praia da Amorosa (Viana do Castelo) and at Mata do Camarido (Caminha), L. sorediomarginata could not be found at these localities. Despite that, its presence in these more northern areas cannot be ruled out. At present it is known only from Portugal.

Selected specimens examined. Portugal: Minho: Esposende, Parque Natural do Litoral Norte, Dunas de Ofir/Fão, Fão, MGRS: 29TNF1894, epiphytic on Pinus pinaster in the border of a pine forest on sand dunes near a road, $2 \mathrm{~m}, 15$ v 2009, S. A. Rodrigues (AVE-L 266, LEB-Lichenes 7826). Douro Litoral: Matosinhos, Angeiras, Parque de Campismo de Angeiras, MGRS: 29TNF2368, $23 \mathrm{~m}$ alt., epiphytic on $P$. pinaster in a small pine stand area used for camping, 15 v 2009, $S$. $A$. Rodrigues (AVE-L 268). Beira Litoral: Ovar, Dunas de Ovar, Cortegaça, MGRS: 29TNF2932, $8 \mathrm{~m}$ alt., epiphytic on $P$. pinaster in a pine forest on sand dunes, $25 \mathrm{vi}$ 2009, S. A. Rodrigues (AVE-L 291, LEB-Lichenes 7827). Aveiro, Reserva Natural das Dunas de S. Jacinto: Dunas de S. Jacinto, S. Jacinto, MGRS: 29TNF2203, $8 \mathrm{~m}$ alt., epiphytic on $P$. pinaster in a pine forest on sand dunes, 23 iv 2009, S. A. Rodrigues (AVE-L 295, LEBLichenes 7828); Ílhavo, Dunas da Gafanha, Gafanha do Carmo, MGRS: 29TNE2394, $13 \mathrm{~m}$ alt., epiphytic on $P$. pinaster in a pine forest on sand dunes, 26 iii 2009, S. A. Rodrigues (AVE-L 235, LEB-Lichenes 7829); Vagos, Dunas de Vagos, Gafanha do Areão, MGRS: 29TNE2185, $21 \mathrm{~m}$ alt., epiphytic on $P$. pinaster in a pine forest on sand dunes, 26 iii 2009, S. A. Rodrigues (AVE-L 298, LEB-Lichenes 7830); Mira, Dunas de Mira, Barra de Mira, MGRS: 29TNE1981, $17 \mathrm{~m}$ alt., epiphytic on $P$. pinaster in a pine forest on sand dunes, 26 iii 2009, S. A. Rodrigues (AVE-L 301, LEB-Lichenes 7831); Figueira da Foz, Dunas de Quiaios, Quiaios, MGRS: 29TNE1654, $49 \mathrm{~m}$ alt., epiphytic on $P$. pinaster, 05 i 2007, S. A. Rodrigues (AVE-L 218); MGRS: 29TNE1554 (BG-L 88210); ibid. MGRS: 29TNE1655,

FIG. 2. Lecanora sorediomarginata. A, margin of the thallus, where the thin prothallus is visible as well as warts that lead to soralia; B, older, entirely sorediate part of the thallus; C, consoredium, with three component-soredium; D, apothecia with a consorediate, flexuose margin; E, section of an apothecium under polarized light, crystals are present in the epihymenium, subhymenium, hypothecium, and consoredia; F, ascus with some septate spores, septation observed in both immature and mature spores; $\mathrm{G}$, ascus with simple spores; $\mathrm{H}$, section of an apothecium seen under UV fluorescence, a substance present in the epihymenium and in the consoredia of the amphithecium fluoresces UV+ yellow, in the subhymenium, hypothecium, parathecium is another UV+ red substance; I, section of an apothecium seen under UV filter, where the UV+ yellow fluorescence is visible in the epihymenium and the consoredia both in the amphithecium and under the apothecium. Scales: A \& B = 0.2 mm; C = $10 \mu \mathrm{m} ; \mathrm{D}=0.5 \mathrm{~mm}$; $\mathrm{F} \& \mathrm{G}=5 \mu \mathrm{m} ; \mathrm{H} \& \mathrm{I}=100 \mu \mathrm{m}$. 
$49 \mathrm{~m}$ alt., epiphytic on $P$. pinea, 26 vi 2009, S. $A$. Rodrigues (AVE-L 307); MGRS: 29TNE1758, $49 \mathrm{~m}$ alt., epiphytic on a branch of $P$. pinea in a pine forest on sand dunes, 26 vi 2009, S. A Rodrigues (LEB-Lichenes 7832); Figueira da Foz, Mata do Prazo de Santa Marinha/Serra da Boa Viagem, Serra da Boa Viagem, MGRS: 29TNE1149, $205 \mathrm{~m}$ alt., epiphytic on P. pinaster, 26 vi 2009, S. A. Rodrigues (AVE-L 306); MGRS: 29TNE1149, $200 \mathrm{~m}$ alt., epiphytic on $P$. pinea in a pine forest in a mountainous area, 26 vi 2009, $S$. A. Rodrigues (AVE-L 287, LEB-Lichenes 7833); Figueira da Foz, Dunas da Leirosa, Costa de Lavos, MGRS: 29TNE1 137, $21 \mathrm{~m}$ alt., epiphytic on $P$. pinaster in a pine forest on sand dunes, 25 iv 2009, S. A. Rodrigues (AVE-L 264, LEB-Lichenes 7834); Figueira da Foz, Mata do Urso, Leirosa, MGRS: 29TNE1032, $28 \mathrm{~m}$ alt., epiphytic on $P$. pinaster in a pine forest on sand dunes, 25 iv 2009, S. A. Rodrigues (AVE-L 262, LEB-Lichenes 7835); Leiria, Mata do Pedrógão, Pedrógão, MGRS: 29S0416, $24 \mathrm{~m}$ alt., epiphytic on $P$. pinaster in a pine forest on sand dunes, 25 iv 2009, S. A. Rodrigues (AVE-L 303, LEB-Lichenes 7836). Estremadura: Marinha Grande, Pinhal de Leiria, S. Pedro de Muel, MGRS: 29SNE0004, $49 \mathrm{~m}$ alt., epiphytic on $P$. pinaster in a pine forest on sand dunes, 25 iv 2009, S. A. Rodrigues (AVE-L 256, LEB-Lichenes 7837); Nazaré, Mata do Valado, Valado dos Frades, MGRS: 29SMD9882, $27 \mathrm{~m}$ alt., epiphytic on $P$. pinaster in the border of a pine forest on sand dunes, 27 iv 2009, S. A. Rodrigues (AVE-L 246); Torres Vedras, Casal do Seixo, Praia do Seixo, MGRS: 29SMD6834, $46 \mathrm{~m}$ alt., epiphytic on $P$. pinaster in a small pine stand on sand dunes used for recreation, 27 iv 2009, S. A. Rodrigues (AVE-L 251, LEB-Lichenes 7838); Sintra, Parque Natural de Sintra-Cascais, Colares, Praia das Maçãs, MGRS: 29SMC5996, $25 \mathrm{~m}$ alt., epiphytic on $P$. pinaster in a pine stand area on sand dunes heavily used for habitation, 27 iv 2009, S. A. Rodrigues (AVE-L 239, LEB-Lichenes 7839); Sintra, Parque Natural de Sintra-Cascais, Serra de Sintra, Ulgueira, MGRS: 29SMC5992, 265 m alt., epiphytic on $P$. pinaster in a pine forest in a mountainous area, 27 iv 2009, S. A. Rodrigues (AVE-L 292); Sesimbra, Parque Natural da Arrábida, Aldeia do Meco, Praia do Moinho de Baixo, MGRS: 29SMC8459, $24 \mathrm{~m}$ alt., epiphytic on $P$. pinaster in a small pine stand on sand dunes, 01 vi 2009, S. A. Rodrigues (AVE-L 277). Baixo Alentejo: Alcácer do Sal, Reserva Natural do Estuário do Sado: Comporta, Praia da Comporta, MGRS: 29SNC1748, $24 \mathrm{~m}$ alt., epiphytic on $P$. pinaster in a pine forest on sand dunes, 01 vi 2009, S. A. Rodrigues (AVE-L 269); Alcácer do Sal, Reserva Natural do Estuário do Sado: Comporta, Murta, MGRS: 29SNC2651, $19 \mathrm{~m}$ alt., epiphytic on $P$. pinea in a pine forest on sand dunes, 01 vi 2009, S. A. Rodrigues (AVE-L 270); Alcácer do Sal, Mata de Valverde, Albergaria, MGRS: 29SNC4140, $79 \mathrm{~m}$ alt., epiphytic on $P$. pinea in a pine forest on sand dunes, 31 iii 2009, S. A. Rodrigues (AVE-L 234); Santiago do Cacém, Área Florestal de Sines, Relvas Verdes, MGRS: 29SNC2106, $69 \mathrm{~m}$ alt., epiphytic on $P$. pinaster in a pine forest on sand dunes, 03 iv 2009, S. A. Rodrigues (AVE-L 297); Odemira, Parque Natural do Sudoeste Alentejano e
Costa Vicentina, Vila Nova de Milfontes, Praia do Malhão, MGRS: 29SNB1880, $67 \mathrm{~m}$ alt., epiphytic on $P$. pinaster in a pine stand on sand dunes near the beach, 30 v 2009, S. A. Rodrigues (AVE-L 200, LEB-Lichenes 7840); Odemira, Parque Natural do Sudoeste Alentejano e Costa Vicentina, Brejão, Praia do Carvalhal, MGRS: 29SNB1849, $30 \mathrm{~m}$ alt., epiphytic on $P$. pinaster in a small pine stand on sand dunes near the beach, $S$. $A$. Rodrigues 30 v 2009 (AVE-L 274, LEB-Lichenes 7841). Algarve: Aljezur, Parque Natural do Sudoeste Alentejano e Costa Vicentina, Rogil, Praia de Vale dos Homens, MGRS: 29SNB1537, $30 \mathrm{~m}$ alt., epiphytic on $P$. pinaster in a pine stand on sand dunes near the beach, 30 v 2009, S. A. Rodrigues (AVE-L 308); Vila do Bispo, Parque Natural do Sudoeste Alentejano e Costa Vicentina, Sagres, Pinhal de Vale Santo, MGRS: 29SNB0300, $74 \mathrm{~m}$ alt., epiphytic on a branch at breast height of $P$. pinaster, 31 v 2009, S. A. Rodrigues (AVE-L 296), epiphytic on $P$. pinaster in a pine forest on sand dunes, 31 v 2009, S. A. Rodrigues (LEBLichenes 7842); Vila Real de Santo António, Dunas de Vila Real de Santo António, Monte Gordo, Praia do Cabeço, MGRS: 29SPB3515, $7 \mathrm{~m}$ alt., epiphytic on $P$. pinaster in the border of a pine forest on sand dunes, 13 vi 2009, S. A. Rodrigues (AVE-L 284. LEB-Lichenes 7843).

\section{Phylogenetic analysis}

The new sequences, two of $L$. sorediomarginata and one of L. lividocinerea, aligned with sequences acquired from the GenBank, resulted in a matrix of 455 unambiguously aligned characters after Gblocks analysis. The likelihood parameters of the Bayesian analysis are available from the authors upon request. The majority-rule consensus tree based on 20000 trees from the B/MCMC sample is shown in Figure 3.

In the $50 \%$ majority-rule consensus tree, the three specimens of $L$. lividocinerea and $L$. sorediomarginata form a strongly supported clade $(\mathrm{PP}=1)$. The two specimens of $L$. sorediomarginata differed in one substitution and one indel of 3 nucleotides in their ITS sequences. On the other hand, the ITS sequence of $L$. lividocinerea diverged in 58 positions compared to L. sorediomarginata. The phylogenetic position of the group formed by these two taxa is still unclear. Although the group was sister to the 'subfusca' group in the tree obtained from the Bayesian analysis, this relationship was not supported statistically. Likewise, the relationships among the previous groups recognized in the 


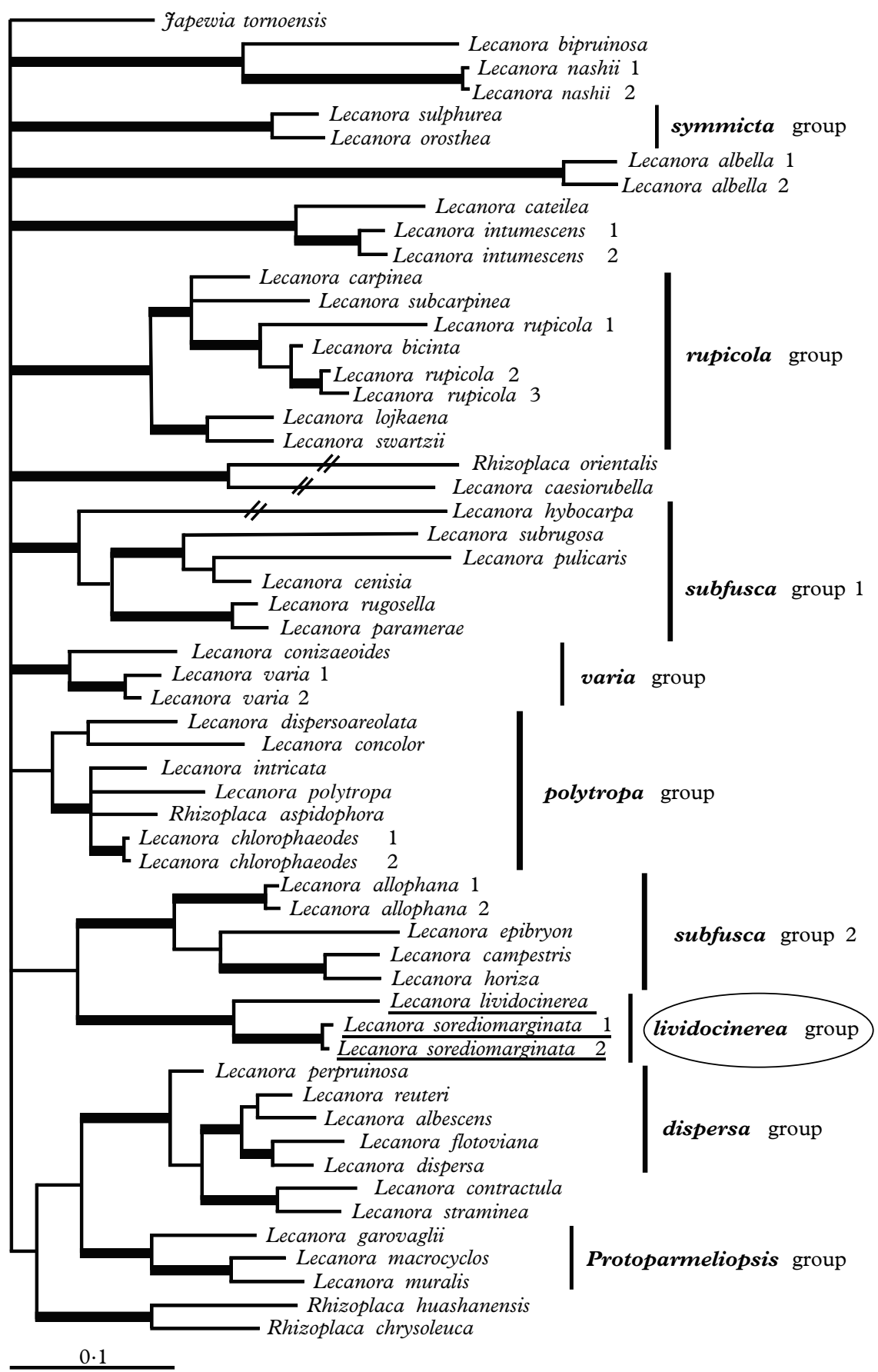

FIG. 3. Phylogenetic tree based on ITS rDNA sequences. Bold branches mean posterior probabilities $\geq 0.95$. 
literature (e.g. Arup \& Grube 1998; Blaha \& Grube 2007; Pérez-Ortega et al. in press) are not well supported in our analysis, probably due to the low number of molecular characters used in the analysis.

\section{Discussion}

The position of Lecanora sorediomarginata within the groups of Lecanora so far defined is not clear. In our phylogenetic analysis $L$. sorediomarginata turned out to be more closely related to L. lividocinerea than to other members of the 'subfusca' group, which seems to indicate the importance of chemistry when defining natural groups within the genus. Unfortunately, fresh material of $L$. sulphurella, which is chemically similar to L. sorediomarginata, was not available at the time of this study. Further research is necessary to determine whether these taxa actually belong to a 'new group' within Lecanora. The absence of an amphithecial cortex and medulla at maturity and the absence of usnic acid or atranorin as major compounds make it difficult to place this species in any particular group based on morphological and chemical characters. Some specimens had minute apothecia with entire margins in the beginning of their development. The margin was found to be composed of entangled hyphae with algal cells, without a clearly defined cortex.

The nature of the amphithecium in $L$. sorediomarginata, which is completely sorediate from early juvenile stages, is not unique within Lecanora. In this regard it is similar to other sorediate species known to have sorediate apothecial margins, but which have an entire margin in the beginning of the apothecial development. These include $L$. barkmaniana Aptroot \& van Herk, L. conizaeoides Nyl. ex Cromb., L. epanora (Ach.) Ach., $L$. expallens Ach., L. farinaria Borrer, L. impudens Degel., L. subaurea Zahlbr. and L. umbrosa Degel. (Tønsberg 1992; Brodo et al. 1994; Aptroot \& van Herk 1999; Ryan et al. 2004; Edwards et al. 2009).

Lecanora sorediomarginata is a very uniform species in terms of morphology. The thallus always has a granular-sorediate appearance, with warts visible at the margin of the thallus. The older, completely sorediate parts of the thallus may appear as a continuous, cracked granular surface. This may cause it to be confused with Ochrolechia microstictoides Räsänen, which also grows in some of the above localities, but the latter has an obvious episubstratal margin with a mean thickness of $54.5 \mu \mathrm{m}(n=7)$ in which the alga is uniformly distributed. Lecanora sorediomarginata, on the other hand, has an endosubstratal to very thin episubstratal margin, where warts arise and lead to soralia; the alga is not uniformly distributed but only present in the warts, not in between. Futhermore, the chemistry of $O$. microstictoides is quite distinct from that of $L$. sorediomarginata, with variolaric acid with satellite and lichesterinic acids present in the thallus (Tønsberg 1992).

Lecanora sorediomarginata may also be confused with Ochrolechia arborea (Kreyer) Almb., a species characterized by a whitish thallus, which is continuous or warted in the periphery, the continuous margin having a mean thickness of $57 \cdot 0 \mu \mathrm{m}(n=11)$ and warts with a mean thickness of $79.0 \mu \mathrm{m}$ $(n=18)$. The soralia are rounded and usually delimited in specimens growing on branches of Pinus, but may be confluent in specimens on the trunk of the same phorophyte. Chemically $O$. arborea contains gyrophoric acid, lecanoric acid (trace) and lichexanthone (Tønsberg 1992), as well as orsellinic acid (Boqueras et al. 1999).

Only two other Lecanora species were found at the type locality and are also likely to occur at other areas surveyed: L. expallens and L. strobilina (Spreng.) Krieffer. Lecanora expallens usually has a thin, indeterminate, green or pale yellow, sorediate thallus, with predominantly confluent soralia. The apothecia grow to $1 \mathrm{~mm}$ diameter and the disc varies in colour from dull yellow to dark red, with the margin soon becoming sorediate or excluded. It can be readily distinguished from $L$. sorediomarginata by the colour of the thallus and its secondary metabolites [thiophanic and usnic acids and zeorin as major substances (Tønsberg 1992)]. Lecanora strobilina has a granular-warted, 
greenish to yellowish grey, esorediate thallus. The apothecia have an average diameter of $0.35 \mathrm{~mm}$, and the yellowish-ochre to orangebrown, flat to convex discs have an entire to crenulate margin, which may be persistent or become excluded. This species contains usnic acid, decarboxysquamatic acid and 士zeorin (Printzen 2001).

No additional sorediate, epiphytic species of Lecanora are known so far from the type locality. Several other European species have an areolate thallus, with initially discrete soralia that later become contiguous, but none of these exhibit a $\mathrm{C}+$ red thalline reaction. A number of these species, including $L$. allophana (Ach.) Nyl. f. sorediata (Schaer.) Vain., L. barkmaniana, L. impudens and $L$. norvegica Tønsberg, contain atranorin or chloroatranorin as a major substance, in addition to other substances (Tønsberg 1992; Aptroot \& van Herk 1999). Lecanora compallens van Herk \& Aptroot and L. flavoleprosa Tønsberg, are also similar in morphology, but contain usnic acid as a major metabolite in addition to other substances (Tønsberg 1992; van Herk \& Aptroot 1999).

Lecanora sorediomarginata contains atranorin and chloroatranorin in only minor amounts and traces of usnic acid and does not contain any other substances in common with these species. Lecanora conizaeoides could also be considered a similar species, not only because it has an aerolate thallus with soralia that become confluent, but also due to the \pm sorediate thalline exciple (Tønsberg 1992). Nevertheless, the presence of fumarprotoetraric acid as a major compound clearly distinguishes this species chemically. Lecanora variolascens $\mathrm{Nyl}$. has a rimose-aerolate thallus, but the soralia are usually well delimited and rarely become confluent; it contains atranorin and psoromic acid as major substances (Lumbsch et al. 1997).

Chemically, $L$. sorediomarginata is similar to the epiphytic L. lividocinerea Bagl. and to the saxicolous L. sulphurella Hepp. Lecanora lividocinerea is characterized by a yellowish-white to whitish-grey thallus, which is esorediate, thin to thick, and with dispersed verrucae or verruculae. The apothecia are sessile, with pale yellow to pale red-brown or grey-brown discs, which may be epruinose or slightly whitish grey pruinose. The thalline exciple is concolorous with the thallus thin, entire, and tverrucose to verruculose (Lumbsch \& Elix 2004). It contains atranorin [major], 3,5dichloro-2'-O-methylanziaic acid [major], chloroatranorin [minor], 5'-chloro- $2^{\prime}-O-$ methylanziaic acid [minor], 3,5-dichloro-2'$O$-methylnorhyperlatolic acid [minor] and 3,5-dichloro-2'-O-methylnorstenosporic acid [minor] (Elix et al. 1997; Lumbsch \& Elix 2004). It is known from coastal localities in Portugal (van den Boom \& Giralt 1996; Carvalho et al. 2002; Paz-Bermúdez \& López de Silanes 2007) and it occurs in other coastal localities in the Mediterranean (PazBermúdez \& López de Silanes 2007) as well as in Australia (Lumbsch \& Elix 2004). Lecanora sulphurella has a grey to bright yellow, rimoseaerolate thallus with sessile apothecia, which have a slightly pruinose black disc and a persistent margin of the same colour as the thallus (Follmann 1976). It contains atranorin [major], chloroatranorin [major], 3,5-dichloro2'-O-methylanziaic acid [major] and calycin [minor] (Lumbsch \& Feige 1992). It is known in the Macaronesian area and from the Iberian Peninsula (Llimona \& Werner 1975; Follmann 1976; Lumbsch \& Feige 1992).

The Instituto da Conservação da Natureza e da Biodiversidade (ICNB), the Natural Parks of LitoralNorte, Sintra-Cascais, Arrábida and Sudoeste Alentejano, and the Nature Reserves of S. Jacinto and Estuário do Sado are thanked for permissions to search for and collect $L$. sorediomarginata in their areas and also for information on the location of pine forest patches. We thank Eng. Isabel Mata (Autoridade Florestal Nacional, AFN) for permission to search and collect $L$. sorediomarginata in Serra de Sintra, and for a guided visit to that locality. We also thank Carla Quintaneiro, Salomé Menezes (Universidade de Aveiro, Portugal) and Rui Costa for their company during some of the field trips, Paz Herráez and Serafín Pérez (Universidad de León, Spain) for performing and teaching how to cut microtome sections, Antonio Sanchez and Silvia González (Universidad de León, Spain) for performing SEM analysis and assistance in the Microscopy Service, Per Magnus Jørgensen (University of Bergen, Norway) for revising the Latin diagnosis and Cristina Azevedo for producing the map in Figure 1. The first author was supported by Fundação para a Ciência e Tecnologia (SFRH/BD/18541/2004) and part of this work was supported by FCT Project Grant reference PTDC/AMB/ $76006 / 2006$. 


\section{REFERENCES}

Akaike, H. (1974) New look at statistical-model identification. IEEE Transactions on Automatic Control AC19: 716-723.

Almeida, A. C. (1997) Dunas de Quiaios, Gândara e Serra da Boa Viagem: uma abordagem ecológica da paisagem. Lisboa: Fundação Caloust Gulbenkian Junta Nacional de Investigação Científica e Tecnológica.

Aptroot, A. \& van Herk, C. M. (1999) Lecanora barkmaneana, a new nitrophilous sorediate corticolous lichen from the Netherlands. Lichenologist 31: 3-8.

Arroteia, J. C. (2009) Leiria e o Pinhal Litoral: Sistema Geogáfico e Contextos de Desenvolvimento. Aveiro: Universidade de Aveiro.

Arup, U. \& Grube, M. (1998) Molecular systematics of Lecanora subgenus Placodium. Lichenologist 30: 415-425.

Arup, U. \& Grube, M. (2000) Is Rhizoplaca (Lecanorales, lichenized Ascomycota) a monophyletic genus? Canadian Fournal of Botany 78: 318-327.

Blaha, J. \& Grube, M. (2007) The new species Lecanora bicinctoidea, its position and considerations about phenotypic evolution in the Lecanora rupicola group. Mycologia 99: 50-58.

Boqueras, M., Barbero, M. \& Llimona, X. (1999) The genus Ochrolechia A. Massal. (Pertusariaceae, lichens) in Spain and Portugal. Cryptogamie Mycologie 20: 303-328.

Brodo, I. M. (1984) The North American species of the Lecanora subfusca group. Beiheft zur Nova Hedwigia 79: 63-185.

Brodo, I. M., Owe-Larsson, B. \& Lumbsch, T. (1994) The sorediate, saxicolous species of the Lecanora subfusca group in Europe. Nordic Fournal of Botany 14: 451-461.

Carvalho, P., Figueira, R., Jones, M., Sérgio, C., Sim-Sim, M. \& Catarino, F. (2002) Dynamics of epiphytic lichen communities in an industrial area of Portugal. Bibliotheca Lichenologica 82: 175-185.

Castresana, J. (2000) Selection of conserved blocks from multiple alignments for their use in phylogenetic analysis. Molecular Biology and Evolution 17: 540-552.

Crespo, A., Blanco, O. \& Hawksworth, D. L. (2001) The potential of mitochondrial DNA for establishing phylogeny and stabilising generic concepts in the parmelioid lichens. Taxon 50: 807-819.

Danielsen, R. (2008) Palaeoecologial development of the Quiaios-Mira dunes, northern-central littoral Portugal. Review of Palaeobotany and Palynology 152: 74-99.

Edgar, R. C. (2004) MUSCLE: multiple sequence alignment with high accuracy and high throughput. Nucleic Acids Research 32: 1792-1797.

Edwards, B., Aptroot, A., Hawksworth, D. L. \& James, P. W. (2009) Lecanora Ach. in Luyken (1809). In The Lichens of Great Britain and Ireland. (C. W. Smith, A. Aptroot, B. J. Coppins, A. Fletcher, O. L. Gilbert, P. W. James \& P. A. Wolseley, eds): 465-502. London: British Lichen Society.
Elix, J. A. \& Ernst-Russell, K. D. (1993) A Catalogue of Standardized Thin Layer Chromatographic Data and Biosynthetic Relationships for Lichen Substances. Canberra: Australian National University.

Elix, J. A., Barclay, C. E., Lumbsch, H. T. \& Wardlaw, J. H. (1997). New chloro depsides from the lichen Lecanora lividocinerea. Australian fournal of Chemistry 50: 971-975.

Elix, J. A., Giralt, M. \& Wardlaw, J. H. (2003) New chloro-depsides from the lichen Dimelaeana radiata. Bibliotheca Lichenologica 86: 1-7.

Follmann, G. (1976) Observaciones acerca de la flora y vegetación de líquenes de las Islas de Cabo Verde. II. Lecanora sulphurella Hepp. (Lecanoraceae). Cuadernos de Botánica Canaria 26/27: 1-7.

Gardes, M. \& Bruns, T. D. (1993) ITS primers with enhanced specifity for basidiomycetes - application to the identification of mycorrhizae and rusts. Molecular Ecology 2: 113-118.

Grube, M., Baloch, E. \& Arup, U. (2004) A phylogenetic study of the Lecanora rupicola group (Lecanoraceae, Ascomycota). Mycological Research 108: 506-514.

Huelsenbeck, J. \& Ronquist, F. (2001) MrBayes: Bayesian inference of phylogenetic trees. Bioinformatics 17: 754-755.

ICN (2006) Plano Sectorial da Rede Natura 2000. Lisboa: Instituto de Conservacão da Natureza. http:// www.icn.pt/psrn2000/conteudo_plano.htm.

IGEO (2008) Carta Administrativa Oficial de Portugal (CAOP v. 6.0). Lisboa: Instituto Geográfico Português. http://www.igeo.pt/produtos/cadastro/ caop/versao6.htm

LaGreca, S. \& Lumbsch, H. T. (2001) Three species of Lecanora new to North America, with notes on other poorly known lecanoroid lichens. Bryologist 104: 204-211.

Llimona, X. \& Werner, R. G. (1975) Quelques lichens noveaux ou interessantes de la Sierra de Gata (Almeria, SE de l'Espagne). Acta Phytotaxonomica Barcinonensia 16: 1-32.

Lohtander, K., Myllys, L., Sundin, R., Kallersjo, M. \& Tehler, A. (1998) The species pair concept in the lichen Dendrographa leucophaea (Arthoniales): analyses based on ITS sequences. Bryologist 101: 404411 .

Lumbsch, H. T. \& Elix, J. A. (2004) Lecanora. In Flora of Australia (P. M. McCarthy \& K. Mallet, eds): 1262. Melbourne: ABRS/CSIRO.

Lumsch, H. T. \& Feige, G. (1992) The exsiccat "Lecanoroid Lichens". 1. - Comment. Mycotaxon 45: 473-488.

Lumbsch, H. T., Plümper, M., Guderley, R., Feige, G. B. (1997) The corticolous species of Lecanora sensu stricto with pruinose apothecial discs. Symbolae Botanicae Upsalienses 32(1): 131-161.

Lumbsch, H. T., Messuti, M. I. \& Nash, T. H., III (2003) New or overlooked species in the Lecanora subfusca group from Southwestern North America (Lecanorales, Ascomycotina). Bryologist 106: 552-559. 
Myllys, L., Lohtander, K., Kallersjo, M. \& Tehler, A. (1999) Sequence insertions and ITS data provide congruent information on Roccella canariensis and $R$. tuberculata (Arthoniales, Euascomycetes) phylogeny. Molecular Phylogenetics and Evolution 12: 295-309.

Orange, A., James, P. W. \& White, F. J. (2001) Microchemical Methods for the Identification of Lichens. London: British Lichen Society.

Page, R. (1996) TreeView: an application to display phylogenetic trees on personal computers. Computer Applications in the Biosciences 12: 357-358.

Paz-Bermúdez, G. \& Lopez de Silanes, M. E. (2007) The identity of two lichen species described from Portugal by J. Harmand. Bryologist 110: 119-122.

Pérez-Ortega, S., Spribille, T., Palice, Z., Elix, J. A. \& Printzen, C. (2010) A molecular phylogeny of the Lecanora varia group, including a new species from western North America. Mycological Progress: in press. (DOI: 10.1007/s11557-010-0660-y)

Posada, D. (2008) jModelTest: Phylogenetic model averaging. Molecular Biology and Evolution 25: 1253-1256.

Printzen, C. (2001) Corticolous and lignicolous species of Lecanora (Lecanoraceae, Lecanorales) with usnic or isousnic acid in the Sonoran Desert region. Bryologist 104: 382-409.

Rodrigues, S. A., Elix, J. A., Vingada, J. V., Alfonso, A. T. \& Soares, A. M. V. M. (2007) The first records of Hypotrachyna lividescens and $H$. pseudosinuosa in the Iberian Peninsula. Cryptogamie Mycologie 28: 155-157.

Ryan, B. D., Lumbsch, H. T., Messuti, M. I., Printzen, C., Śliwa, L., Nash, T. H., III (2004) Lecanora. In Lichen Flora of the Greater Sonoran Desert Region. II (T. H. Nash III, B. D. Ryan, P. Diederich, C. Gries \& F. Bungartz, eds): 176-286. Tempe, Arizona: Lichens Unlimited, Arizona State University.

Tavaré, S. (1986) Some probabilistic and statistical problems in the analysis of DNA sequences. Lectures on Mathematics in the Life Sciences 17: 57-86.

Tønsberg, T. (1992) The sorediate and isidiate, corticolous, crustose lichens in Norway. Sommerfeltia 14: $1-331$.

van den Boom, P. \& Giralt, M. (1996) Contribution to the flora of Portugal, lichens and lichenicolous fungi. 1. Nova Hedwigia 63: 145-172.

van Herk, C. \& Aptroot, A. (1999) Lecanora compallens and L. sinuosa, two new overlooked corticolous lichen species from Western Europe. Lichenologist 31: 543-553.

White, F. J. \& James, P. W. (1985) A New Guide to Microchemical Techniques for the Identification of Lichen Substances. London: British Lichen Society.

White, T. J., Bruns, T., Lee, S. \& Taylor, J. (1990) Amplification and direct sequencing of fungal ribosomal RNA genes for phylogenetics. In PCR Protocols: A Guide to Methods and Applications (M. A. Innis, D. H. Gelfand, J. J. Sninsky \& T. J. White): 315-322. New York: Academic Press. 